\title{
PENGGUNAAN METODE DISKUSI TERHADAP KETERAMPLAN MENULIS TEKS ULASAN
}

\section{Hendrisman}

STKIP Yayasan Abdi Pendidikan

hendrisman63@gmail.com

Submit, 14-10-2019 Accepted, 25-12-2019 Publish, 25-12-2019

\begin{abstract}
ABSTRAK
Tujuan penelitian ini adalah untuk mendeskripsikan pengaruh penggunaan metode diskusi terhadap keterampilan menulis teks ulasan siswa kelas VIII MTsN DangungDangung Kabupaten Lima Puluh Kota. Metode yang digunakan adalah metode eksperimen. Hasil penelitian menemukan bahwa pembelajaran dengan metode diskusi berpengaruh terhadap keterampilan menulis teks ulasan siswa kelas VIII MTsN Dangung-Dangung Kabupaten Lima Puluh Kota. Analisis data menunjukkan bahwa, metode diskusi berpengaruh dalam keterampilan menulis teks ulasan. Hasil penelitian terbukti adanya kenaikan di kelas eksperimen dengan nilai siswa waktu pretes nilai rata$\operatorname{rata} /$ mean $(\bar{X})$ adalah 67 setelah diterapkan metode diskusi, mengalami kenaikan dengan nilai rata-rata/mean $(\bar{X})$ adalah 83 . Sedangkan dalam nenggunakan metode konvensional nilai siswa juga berpengaruh walaupn kenaikan nilai tidak terlalu tinggi. Waktu pretes nilai rata-rata/mean $(\bar{X})$ adalah 48 . Setelah diterapkan metode konvensional mengalami kenaikan nilai rata-rata/mean $(\bar{X})$ adalah 61. Simpulan, hasil pembelajaran siswa yang diajarkan menggunakan metode diskusi lebih baik dibandingkan hasil pembelajaran siswa dikelas kontrol yang diajarkan dengan pembelajaran konvesional.
\end{abstract}

Kata Kunci: Metode Diskusi, Menulis Teks Ulasan

\section{ABSTRACT}

The purpose of this study was to describe the effect of the use of the discussion method on the writing skills of the eighth grade students' MTsN Dangung-Dangung District Five Puluh City. The method used is an experimental method. The results of the study found that learning by the discussion method affected the writing skills of the eighth grade students of MTsN Dangung-Dangung, Lima Puluh Kota. Data analysis shows that the discussion method has an effect on the skills of writing review texts. This is evidenced by an increase in the experimental class with the student score pretest time mean value $(\bar{x})$ is 67 after the discussion method has been applied, an increase with an average value / mean $(\bar{x})$ is 83 . Whereas in using conventional methods students also value effect even if the increase in value is not too high. The pretest time mean value ( $\bar{x}$ ) is 48. After applying conventional methods, the average value increase (mean) is 61 . So the learning outcomes of students taught using the discussion method are better than the learning outcomes of students in the control class taught with conventional learning.

Keywords: Discussion Method, Writing Review Texts. 


\section{PENDAHULUAN}

Pemahaman terhadap jenis, kaidah dan konteks suatu teks ditekankan sehingga memudahkan peserta didik menangkap makna yang terkandung dalam suatu teks maupun menyajikan gagasan dalam bentuk teks yang sesuai sehungga memudahkan orang lain dalam memahami gagasan yang ingin disampaikan. Salah satu jenis teks yang dipelajari oleh siswa yaitu menulis teks ulasan. teks ulasan merupakan sebuah teks yang dikasilkan dari sebuah analisis terhadap berbagai hal. Analisis itu bisa berbentuk buku, novel, berita, laporan, atau dongeng. Teks tersebut memberikan tanggapan atau analisis yang berhubungan dengan latar, aktu, tempat, serta karakter yang ada didalam teks tersebut. Selanjutnya Thahar (2008) pengertian resensi secara etimologi, resensi berasal dari bahasa Belanda, recensie dan berasal pula dari bahasa Latin recenseo yang berarti memeriksa kembali, meninjau, atau menimbang. Dalam bahasa Inggris resensi disebut review, yang artinya sebuah laporan tanpa kritik tentang suatu peristia kesenian (pertunjukan drama, pameran lukisan, flm, buku, dll). Resensi tidak saja digunakan untuk menimbang atau melaporkan tentang sebuah buku yang baru terbit, melainkan kata resensi juga dipakai untuk resensi flm, pementasan drama, pameran lukisan, resensi music pop, dan lainnya.

Dilihat dari fakta yang ditemukan dalam pembelajaran guru masih menjadi pusat dalam pembelajaran dan sumber belajar untuk siswa sehingga siswa bosan dalam pembelajaran yang diberikan guru. Bahan ajar yang akan digunakan dalam pembelajaran bahasa Indonesia khususnya dalam menulis teks ulasan yang sesuai dengan kurikulum 2013 belum memadai yang menyebabkan sedikitnya bahan rujukkan yang digunakan siswa. keterampilan siswa dalam menulis teks ulasan belum menunjukkan hasil yang maksimal. Guru juga belum menggunakan media yang dapat menarik perhatian siswa, media yang sering digunakan guru hanyalah papan tulis yang digunakan untuk mencatat materi pembelajaran kepada siswa. Hal ini mengakibatkan rendahnya minat belajar siswa, siswa menjadi kurang aktif dalam pembelajaran bahasa Indonesia.

Ketidakaktifan siswa dalam belajar dapat dilihat dari sikap siswa yang kurang bersemangat dalam belajar. Di samping itu, siswa sulit berkonsentrasi saat belajarkarena buku teks yang ada terlalu singkat dan belum lengkap. Anindyarini, $l$ (2008) berpendapat bawasanya resensi adalah ulasan atau pembicaraan mengenai suatu karya baik itu buku, film, atau karya yang lain. Tugas seorang penulis resensi adalah memberikan gambaran 
kepada pembaca mengenai suatu karya yang diresensinya apakah karya tersebut perlu mendapat sambutan atau tidak. Penulis resensi juga membantu penerbit atau pengarang untuk memperkenalkan suatu karya. Selanjutnya menurut Istanun \& Farida (dalam Novitasari, 2015), teks ulasan atau resensi adalah tulisan yang isinya menimbang atau menilai sebuah karya yang dikarang atau dicipta orang lain. Menilai dan menimbang karya dilakukan agar kita bisa melihat bagaimana karya yang ditulis oleh seseorang tersebut baik dari segi produksinya, dari segi keunggulan dan kelemahan karya tersebut.

Dalam pembuatan teks ulasan siswa harus memperhatikan struktur teks ulasan tersebut. Struktur teks ulasan yang harus ada adalah sebagai berikut (1) orientasi, yaitu berisi gambaran umun tentang karya sastra yang akan diulas (2) tafsiran, yaitu berisi pandangan sendiri pengulas tentang karya yang diulas (3) evaluasi, yaitu penulis mengevaluasi karya, penampilan, dan produksi. Evaluasi juga berisi gambaran detail dari karya yang diulas (4) rangkuman, yaitu berisi ulasan akhir penulis yang berisi simpulan karya tersebut. Kebahasaan teks ulasan yaitu. (1) kata sifat sikap, berfungsi mendeskripsikan pelaku dalam penampilan fisik,/kepribadiannya (2) kata benda dana kata kerja, yakni kata kerja adalah kata yang menyatakan suatu tindakan, perbuatan, aktifitas. Kata benda yakni kata yang mengacu pada manusia, binatang, benda, dan konsep atau pengertian (3) metafora, yakni pemakaian kata atau kelompok kata bukan dengan arti yang sebenarnya, melainkan sebagai lukisan yang berdasarkan persamaan/perbandingan (4) kalimat dalam teks ulasan, ada kalimat majemuk setara dan kalimat majemuk bertingkat, (5) kata rujukan, yakni kata yang menunjukkan rujukan, baik yang merujuk dan dirujuk.

Dalam diskusi setiap orang diharapkan memberikan pendapat sehingga seluruh kelompok kembali dengan pemahaman yang sama dalam satu keputusan atau kesimpulan. Dengan berdiskusi akan membiasakan siswa untuk menghargai pendapat orang lain. Bulatau (1985), berpendapat diskusi berkelompok dapat dirumuskan dari dua unsur yaitu berpikir dan bersama. Berpikir adalah tindakan yang paling wajar bagi setiap manusia, namun juga paling sulit pelaksanaannya dengan baik. Yang mendorong orang bergabung dalam berpikir adalah usaha untuk mengetahui realistis tidaknya pemikiran sendiri apabila dikaji dengan pengalaman bersama.

Teknik pembelajaran diskusi setiap pengajar menciptakan terjadinya kegiatan atau interaksi antara dua atau lebih individu yang terlibat, saling tukar informasi, 
pengalaman, memecahkan masalah, sehingga terjadi suasana yang aktif antara peserta didik. Dengan berdiskusi peserta didik menjadi lebih mudah dalam menyelesaikan tugas yang diberikan. Peserta didik juga akan lebih aktif dalam proses pembelajaran. Dalam pembelajaran diskusi merupakan interaksi antara siswa dengan siswa atau siswa dengan guru untuk menganalisis, memecahkan masalah, menggali, memperdebatkan topik atau permasalahan tertentu. Diskusi dapat melatih siswa dalam menghargai pendapat orang lain. Dengan berdiskusi akan membiasakan siswa untukberagumentasi dan berpikir rasional. Hamzah \& Mohamad (2012) diskusi kelompok merupakan metode yang menghendaki agar siswa dan guru serta siswa dengan siswa lainnya terjadi interaksi dan saling tukar pengalaman dan informasi dalam memecahkan suatu masalah. Kegiatan ini mendorong siswa untuk berinteraksi dan membantu memahami pendapat berbeda yang mungkin selama kegiatan berlangsung. Kegiatan ini juga mendorong siswa agar dapat menghargai pendapat orang lain.

Hasil penelitian Walef (2018), terdapat pengaruh pembelajaran kooratif tipe jigsaw terhadap keterampilan membaca. Menurut Henawati (2015) ada pengaruh metode demontrasi terhadap kemampuan siswa menulis teks prosedur. Permatasari (2018) ada pengaru metode karyawisata (Fild Trip) terhadap kemampuan menulis teks puisi siswa. Selanjutnya, Yulia (2017) terdapat pengaruh model problem bassed learningberbantuan media audio visual terhadap keterampilan menulis teks ulasan. Namun dalam penelitian ini menggunaan metode diskusi terhadap keterampilan menulis teks ulasan. Diskusi merupakan suatu kegiatan untuk memecahkan suatu masalah dengan maksud untuk mendapat pengertian bersama yang lebih jelas dan lebih teliti tentang sesuatu, atau untuk merampungkan keputusan bersama.

\section{METODE PENELITIAN}

Jenis penelitian ini adalah penelitian kuantitatif. Dinamakan penelitian kuantitatif karena penelitian data yang akan dikumpulkan berupa angka. Populasi dalam penelitian ini adalah siswa kelas VIII MTsN Dangung-dangung yang berjumlah 196 orang.sampel adalah bagian dari populasi. Untuk pengambilan sampel, penulis menggunakan teknik proposive sampling.Instrumen yang digunakan dalam penelitian ini adalah tes. Dengan demikian tes dapat digunakan sebagai alat untuk mengukur kemampuan siswa. Dalam penelitian ini pengumpulan data dilakukan dengan cara 
memberikan tes kepada siswa berupa menulis teka ulasan tanpa menggunakan metode diskusi (pretest) dan terakhir siswa disuruh menulis teks ulasan dengan metode diskusi (posttest).Teknik analisis data yang digunakan dalam penelitian kuantitatif yaitu diarahkan untuk menjawab rumusan masalah atau menguji hipotesis yang telah dirumuskan dalam proposal. Karena datanya kuantitatif, maka teknik analisis data menggunakan metode statistik yang sudah tersedia. Berdasarkan hal tersebut maka langkah-langkah yang akan dilakukan pada tahap analisis data adalah sebagai berikut (1) Membaca tulisan yang sudah dikumpulkan (2) Menentukan skor keterampilan siswa berdasarkan indikator-indikator yang diteliti (3) Mengubah skor menjadi nilai antara pretest dan posttest (4) Melakukan uji normalitas uji homogenitas dan uji hipotesis

\section{HASIL PENELITIAN}

Penelitian ini diawali dari pertemuan pertama adalah memberikan te awal pada (preetes) untuk mengukur kondisi awal siswa pada kedua kelas. Kemudian memberikan seperangkat perlakuan dengan menerapkan metode diskusi pada kelas eksperimen dan metode ceramah pada kelas kontrol.Setelah mendapatkan data penulis mendeskripsikan data yang meliputi gambaran tentang pengaruh metode diskusi pada kelas eksperimen dan kelas kontrol. Juga menguraikan perbedaan yang signifikan antara metode diskusi dan metode konvensional terhadap keterampilan menulis ulasan.

\section{Metode Diskusi (Kelas Esperimen)}

Berdasarkan hasil dari prates dan pascates, maka didapat perhitungan statistik pada kelas eksperimen sebagai berikut:

Tabel 1

Data Statistik Kelas Eksperimen

\begin{tabular}{lcl}
\hline \multicolumn{1}{c}{ Tes } & $\boldsymbol{\Sigma}$ & $\bar{X}$ \\
\hline Prates & 1618 & 67 \\
\hline Pascates & 1994 & 83 \\
\hline
\end{tabular}

Dari hasil tabel di atas dapat disimpulkan bahwa adanya pengaruh metode diskusi dalam pembelajaran menullis ulasan di kelas eksperimen. Hal ini dibuktikan dengan adanya peningkatan nilai siswa, yang mana pada waktu prates total nilai $(\Sigma)$ 1618 dan nilai rata-rata/mean $(\bar{X})$ adalah 67 . Setelah diterapkan metode diskusi dalam 
proses belajar di kelas ini, didapat peningkatan hasil pembelajaran siswa pada waktu pascates dengan total nilai $(\Sigma) 1994$ dan nilai rata-rata $(\bar{X}) 83$.

\section{Metode Konvensional pada Kelas Kontrol}

Pada kelas kontrol, siswa diajar dengan menggunakan metode konvensional. Perhitungan statistik yang didapat setelah pascates pada kelas kontrol adalah sebagai berikut:

Tabel 2

Data Statistik Kelas control

\begin{tabular}{lcl}
\hline \multicolumn{1}{c}{ Tes } & $\boldsymbol{\Sigma}$ & $\bar{X}$ \\
\hline Prates & 1143 & 48 \\
\hline Pascates & 1456 & 61 \\
\hline
\end{tabular}

Dari hasil tabel di atas dapat disimpulkan bahwa adanya pengaruh metode konvensional dalam pembelajaran menulis ulasan di kelas kontrol. Hal ini dibuktikan dengan adanya peningkatan nilai siswa, yang mana pada waktu prates total nilai $(\Sigma)$ 1143 dan nilai rata-rata/mean $(\bar{X})$ adalah 48. Setelah diterapkan metodekonvensional dalam proses belajar di kelas ini, didapat peningkatan hasil pembelajaran siswa pada waktu pascates dengan total nilai $(\Sigma) 1456$ dan nilai rata-rata $(\bar{X}) 61$.

\section{Perbedaan Signifikan Antara Hasil Menulis Ulasan dengan Menggunakan Metode Diskusi dan Metode Konvensional}

Untuk melihat perbedaan signifikan antara hasil pembelajaran menulis ulasan dengan metode diskusi dan metode konvensional, penulis melakukan perbandingan nilai pascates antara kedua kelas:

Tabel 3

Perbandingan Nilai Pascates

\begin{tabular}{cccccc}
\hline \multirow{2}{*}{ Kelas Eksperimen } & \multicolumn{3}{c}{ Kelas Kontrol } \\
\hline Jumlah Skor & $\mathrm{N}$ & $\bar{X}$ & Jumlah Skor & $\mathrm{N}$ & $\bar{X}$ \\
\hline 1994 & 24 & 83 & 1456 & 24 & 61 \\
\hline
\end{tabular}

Dari tabel di atas dapat dilihat rata-rata kelas eksperimen (83) lebih besar dibanding kelas kontrol (61). Hal ini menunjukkan bahwa adanya perbedaan yang signifikan antara hasil keterampilan menulis ulasan siswa dengan menggunakan metode 
diskusi dibanding penggunaan metode konvensional.Dapat disimpulkan bahwa dalam penelitian ini penggunaan metode diskusi lebih efektif dari pada penggunaan metode konvensional.

Maka data tersebut dianalisa dengan menggunakan tiga pengujian yaitu, uji normalitas, uji homogenitas, uji t (t-test). Pengujian ini pada akhirnya berguna untuk menguji hipotesis mana yang akan diterima. Berikut ini adalah penjelasan dari tiap pengujian tersebut:

\section{Uji Normalitas}

Uji normalitas data dilakukan untuk menguji apakah data yang diteliti berdistribusi normal atau tidak.Untuk menganalisa datanya digunakan rumus Uji Liliefors. Pengujian ini dilakukan pada kedua kelas: kelas eksperimen dan kelas kontrol, dan data yang digunakan adalah data dari hasil pascates. Data tersebut disimbolkan dengan $\mathrm{X}_{\mathrm{i}}$, kemudian ditranformasikan dalam nilai $\mathrm{Zi}$ dari angka ke notasi pada distribusi normal dengan menggunakan $\bar{X}$ dan SD dari data. Setelah itu dihitung probabilitas komulatif normal $\left(\mathrm{F}_{(\mathrm{zi})}\right)$ dan probabilitas komulatif empirisnya $\left(\mathrm{S}_{(\mathrm{zi})}\right)$. Kemudian diuji signifikansinya dengan menghitung selisih $\left\{\mathrm{F}_{(\mathrm{zi})}-\mathrm{S}_{(\mathrm{zi})}\right\}$, dan nilai terbesarnya (Liliefors hitung $=\mathrm{L}_{\mathrm{o}}$ ) dibandingkan dengan nilai Liliefors tabel $\left(\mathrm{L}_{\mathrm{t}}\right)$. Untuk mencari $\mathrm{L}_{\mathrm{t}}$ dalam penelitian ini digunakan derajat kepercayaan $(\mathrm{dk} / \alpha)$ 0.05.Jika nilai $\mathrm{L}_{\mathrm{o}}<\mathrm{L}_{\mathrm{t}}$, maka data berdistribusi normal.Namun apabila $\mathrm{L}_{\mathrm{o}}>\mathrm{L}_{\mathrm{t}}$, maka data tidak berdistribusi normal. Hasil uji normalitas pada penelitian ini dapat dilihat pada tabel berikut:

Tabel 4.

Hasil Perhitungan Uji Normalitas

\begin{tabular}{lccccccc}
\hline Kelas & $\mathbf{n}$ & $\overline{\boldsymbol{X}}$ & $\mathbf{S D}$ & $\boldsymbol{\alpha}$ & $\mathbf{L}_{\mathbf{o}}$ & $\mathbf{L}_{\mathbf{t}}$ & Ket. \\
\hline Eksperimen & 24 & 83 & 15.947 & 0.05 & 0.1556 & 0.1808 & Normal \\
\hline Kontrol & 24 & 61 & 10.633 & 0.05 & 0.2450 & 0.1808 & Normal \\
\hline
\end{tabular}

Tabel di atas menunjukkan bahwa pada kedua kelas nilai Lo lebih kecil dibanding nilai Lt, ini berarti sebaran data pada hasil pembelajaran menulis ulasan siswa yang diajar dengan metode diskusi di kelas eksperimen dan metode konvensional di kelas kontrol berdistribusi normal. 


\section{Uji Homogenitas}

Uji homogenitas dilakukan untuk melihat apakah data mempunyai varians yang homogen atau tidak.Pada penelitian ini, penulis menggunakan Uji Harley.Uji Harley digunakan dengan menbandingkan variansi terbesar dengan variansi terkecil dari data. Kemudian hasil dari $F_{\text {hitung }}$ dibadingkan dengan hasil dari $F_{\text {tabel }}$, dengan $\mathrm{df}=\mathrm{n}-1$ dan $\mathrm{k}=2$. Maka didapat hasil sebagai berikut:

Tabel 5

Hasil Perhitungan Uji Homogenitas

\begin{tabular}{cc}
\hline$S_{1}^{2}$ & 102.318 \\
\hline$S_{2}^{2}$ & 129.121 \\
\hline $\mathrm{F}_{\text {hitung }}\left(\mathrm{F}_{\mathrm{n}}\right)$ & 0.79 \\
\hline $\mathrm{N}$ & 24 \\
\hline $\mathrm{K}$ & 2 \\
\hline $\mathrm{F}_{\text {tabel }}\left(\mathrm{F}_{\mathrm{t}}\right)$ & 3.4 \\
\hline
\end{tabular}

Dari tabel di atas dapat disimpulkan bahwa $F_{n}$ lebih kecil dari $F_{t}(1.79<3.40)$. ini berarti variansi dari penelitian ini bersifat homogen.

\section{Uji t (t-test)}

Uji $\mathrm{t}$ adalah langkah terakhir yang digunakan dalam penelitian ini. Uji $\mathrm{t}$ digunakan untuk mencari nilai $t_{\text {hitung }}$ yang akan dibandingkan dengan nilai $t_{\text {tabel }}$, dengan tujuan untuk menentukan hipotesis mana yang diterima. Sebelum melakukan uji t, penulis mancari nilai standar deviasi gabungan $\left(\mathrm{S}_{\mathrm{gab}}\right)$ terlebih dahulu dengan rumus sebagai berikut:

$$
S_{g a b}=\frac{\left(n_{1}-1\right) S_{1}^{2}+\left(n_{2}-1\right) S_{2}^{2}}{n_{1}+n_{2}-2}
$$

Setelah didapat nilai $S_{g a b}: 6.596$, maka nilai tersebut digunakan pada rumus uji t berikut ini:

$$
t=\frac{\overline{X_{1}}-\bar{X}_{2}}{S \sqrt{\frac{1}{n_{1}}+\frac{1}{n_{2}}}}
$$

Dari perhitungan di atas didapat nilai $t_{\text {hitung: }}$ 3.82092. Kemudian nilai tersebut dibandingkan dengan nilai $t_{\text {tabel }}$ untuk menentukan hipotesis mana yang akan diterima, dan pembahasan tersebut dijelaskan pada sub pokok pengujian hipotesis berikut. 


\section{Pengujian Hipotesis}

Pengujian hipotesis dilakukan dengan membandingkan nilai prates dengan pascatest dari kelas eksperimen. Langkah awal adalah dengan menetukan $\overline{\boldsymbol{X}}$ dan SD dari nilai skor masing-masing tes. Kemudian data tersebut digunakan untuk mencari standar deviasi gabungan $\left(\mathrm{S}_{\mathrm{gab}}\right)$. Langkah selanjutnya adalah dengan menggunakan data tersebut

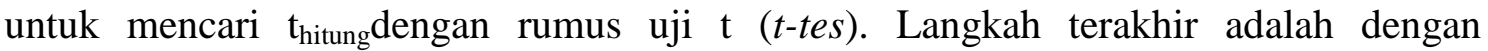
membandingkan nilai $t_{\text {hitung }}$ dengan $t_{\text {tabel }}$. Hasilnya adalah sebagai berikut:

Tabel 6.

Hasil Perhitungan Uji t Eksperimen

\begin{tabular}{llll}
\hline Eksperimen & $\mathbf{N}$ & $\overline{\boldsymbol{X}}$ & SD \\
\hline Prates & 24 & 67 & 16.88 \\
\hline Pascates & 24 & 83 & 10.32 \\
\hline $\mathrm{S}_{\text {gab }}: 15.9473$ & & & \\
\hline $\mathrm{t}_{\text {hitung }}: 4.9152$ & & \\
\hline $\mathrm{t}_{\text {tabel }}: 2.021\left(\right.$ dengan df: $\mathrm{n}_{1}-1=22$ dan $\left.\alpha: 0.05\right)$ & \\
\hline
\end{tabular}

Dari tabel di atas dapat dilihat bahwa nilai $t_{\text {hitung }}$ lebih besar dari $t_{\text {tabel }}\left(t_{\text {hitung }}=\right.$ 4.9152>t $\mathrm{t}_{\text {tabel }}=2.021$ ). Ini berarti $\mathrm{H}_{\mathrm{a}}$ (hipotesis alternatif) diterima, yaitu adanya pengaruh metode diskusi terhadap keterampilan menulis ulasan siswa.

Pengujian hipotesis dilakukan dengan membandingkan nilai prates dengan pascatest dari kelas kontrol. Langkah awal adalah dengan menetukan $\overline{\boldsymbol{X}}$ dan SD dari nilai skor masing-masing tes. Kemudian data tersebut digunakan untuk mencari standar deviasi gabungan $\left(\mathrm{S}_{\mathrm{gab}}\right)$. Langkah selanjutnya adalah dengan menggunakan data tersebut

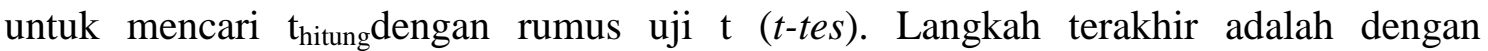
membandingkan nilai $t_{\text {hitung }}$ dengan $t_{\text {tabel }}$. Hasilnya adalah sebagai berikut:

Tabel 7

Hasil Perhitungan Uji t kontrol

\begin{tabular}{|c|c|c|c|}
\hline Kontrol & $\mathbf{N}$ & $\bar{X}$ & SD \\
\hline Prates & 24 & 48 & 9.72 \\
\hline Pascates & 24 & 61 & 11.60 \\
\hline$: 12.4729$ & & & \\
\hline$: 5.1060$ & & & \\
\hline$: 2.021(\mathrm{de}$ & $\mathrm{df}: \mathrm{n}$ & dan & \\
\hline
\end{tabular}


Dari tabel di atas dapat dilihat bahwa nilai $t_{\text {hitung }}$ lebih besar dari $t_{\text {tabel }}$ $\left(t_{\text {hitung }}=5.1060>t_{\text {tabel }}=2.021\right.$ ). Ini berarti $H_{a}$ (hipotesis alternatif) diterima, yaitu adanya pengaruh metode konvensional terhadap keterampilan menulis ulasan.

Pengujian hipotesis dilakukan dengan menbandingkan nilai dari kedua kelas yang didapat dari nilai pascates.Langkah awal adalah dengan menentukan $\overline{\boldsymbol{X}}$ dan SD dari tiap kelas, kemudian data tersebut digunakan untuk mencari standar deviasi gabungannya $\left(S_{\text {gab }}\right)$.Langkah selanjutnya adalah dengan menggunakan data tersebut untuk mencari $\mathrm{t}_{\text {hitung }}$ dengan rumus uji $\mathrm{t}(\mathrm{t}$-tes).Langkah terakhir adalah dengan membandingkan nilai $t_{\text {hitung }}$ dengan $\mathrm{t}_{\text {tabel }}$. Hasilnya adalah sebagai berikut:

Tabel 8

Hasil Perhitungan Uji t

\begin{tabular}{llll}
\hline \multicolumn{1}{c}{ Kelas } & $\mathbf{N}$ & $\overline{\boldsymbol{X}}$ & SD \\
\hline Eksperimen & 24 & 83 & 15.9473 \\
\hline Kontrol & 24 & 61 & 12.4729 \\
\hline $\mathrm{S}_{\text {gab }}: 10.756$ & & \\
\hline $\mathrm{t}_{\text {hitung }}: 7.3065$ & & \\
\hline $\mathrm{t}_{\text {tabel }}$ & $: 2.021\left(\right.$ dengan df: $\mathrm{n}_{1}+\mathrm{n}_{2}-2=46$ dan $\left.\alpha: 0.05\right)$ \\
\hline
\end{tabular}

Dari tabel di atas dapat dilihat bahwa nilai $t_{\text {hitung }}$ lebih besar dari $t_{\text {tabel }}$ $\left(t_{\text {hitung }}=7.3065>t_{\text {tabel }}=2.021\right.$ ). Ini berarti $H_{a}$ (hipotesis alternatif) diterima, yaitu adanya perbedaan yang signifikan antara keterampilan menulis ulasanyang diajar dengan metode diskusi dibanding dengan siswa yang diajar dengan metode konvensional.

Hasil penelitian menunjukkan bahwa adanya perbedaan kemampuan antara siswa yang diajar dengan metode diskusi dengan siswa yang diajar dengan metode konvensional. Dengan kata lain metode diskusi lebih efektif dibanding metode konvensional.

\section{PEMBAHASAN}

\section{Pengaruh Metode Diskusi dalam keterampilan menulis Ulasan}

Berdasarkan hasil analisis yang telah dilakukan, bahwa pembelajaran menulis ulasan dengan metode diskusi berpengaruh terhadap nilai siswa. Sejalan dengan pendapat Hamzah \& Mohamad (2012) diskusi merupakan metode yang menghendaki agar siswa dan guru serta siswa dengan siswa lainnya terjadi interaksi dan saling tukar pengalaman dan informasi dalam memecahkan suatu masalah. Hal ini dibuktikan 
dengan adanya kenaikan nilai siswa, yang mana pada waktu prates total nilai $(\Sigma) 1.618$ dangan nilai rata-rata/mean $(\bar{X})$ adalah 67. setelah diterapkan metode diskusi dalam proses pembelajaran menulis ulasan maka nilai siswa mengalami kenaikan pada waktu pascates dengan total nilai $(\Sigma) 1.994$ dan nilai rata-rata /mean $(\bar{X}) 83$. Ternyata metode diskusi sesuai digunakan dalam pembelajaran keterampilan menulis ulasan siswa dalam metode diskusi dapat bertukar pikiran dan dapat menemukan ide-ide baru dalam menulis, karena sering melakukan latihan. Sehingga mereka mampu memperoleh hasil yang baik dalam menulis.

\section{Pengaruh Metode Konvensional Dalam Keterampilan Menulis Ulasan}

Berdasarkan hasil analisis yang telah dilakukan, bahwa pelajaran menulis ulsan dengan metode konvensional berpengaruh terhadap nilai siswa. Hal ini dibuktikan dengan adanya kenaikan nilai siswa, yang mana pada waktu prates total nilai $(\Sigma) 1.143$ dangan nilai rata-rata/mean $(\bar{X})$ adalah 48. Setelah diterapkan metode konvensional dalam proses pelajaran menulis ulasan maka nilai siswa mengalami kenaikan pada waktu pascates dengan total nilai $(\Sigma) 1.456$ dan nilai rata-rata /mean $(\bar{X}) 61$. Pembelajaran dengan metode konvensional dalam pengajaran keterampilan menulis memang mengalami kenaikan, tetapi kenaikan nilainya tidak terlalu tinggi.. Jadi, berdasarkan pemerolehan data di atas dapat disimpulkan metode konvensional kurang sesuai diterapkan pada pengajaran keterampilan menulis ulasan.

\section{Perbedaan Hasil Keterampilan menulis Ulasan dengan metode diskusi dan metode}

\section{konvensional}

Berdasarkan hasil analisis perbandingan hasil keterampilan menulis ulasan antara metode diskusi dan metode konvensional dapat dilihat dari rata-rata kelas eksperimen (diskusi) 83 lebih besar dibandingkan dengan kelas kontrol (konvensional) 61. Hal ini menunjukkan perbedaan yang signifikan antara hasil keterampilan menulis ulasan metode diskusi dibanding penggunaan metode konvensional. Dapat dismpulkan bahwa dalam penelitian ini penggunaan metode diskusi lebih efektif daripada penggunaan metode konvensional.

Selain perhitungan statistik yang membuktikan bahwa metode diskusi lebih baik dibandingkan dengan metode konvensional pada hasil menulis ulasan siswa, hasil 
observasi juga menunjukkan hal yang serupa,yaitu dalam prosespenerapan metode diskusi siswa terlihat lebih aktif dari pada metode konvensional.

\section{SIMPULAN}

Hasil pembelajaran siswa yang diajarkan menggunakan metode diskusi lebih baik dibandingkan hasil pembelajaran siswa dikelas kontrol yang diajarkan dengan pembelajaran konvesional.

\section{DAFTAR PUSTAKA}

Anindyarini, A. (2008). Bahasa Indonesia: SMP/MTs. Jakarta: Pusat Pembukuan Departemen Pendidikan Nasional.

Bulatau. (1985). Teknik diskusi berkelompok. Yogyakarta.

Hamzah, N., M. (2012). Belajar dengan Pendekatan PAILKEM (Aktif, Inofatif, Lingkungan, Kreatif, Efektif, Menarik). Jakarta: Bumi Aksara.

Hernawati. (2015). Pengaruh Metode Demontrasi terhadap Kemampuan Siswa Menulis Teks Prosedur, 184-192

Novitasari. (2015). Kemampuan Menulis Teks Ulasan/Resensi Siswa Kelas VIII SMP Negeri 2 Kotagajah. Jurnal (Bahasa, Sastra, dan Pembelajarannya.Lampung:FKIP Universitas Lampung

Permatasari, D. (2018). Pengaruh Metode Karyawisata (Fild Trip) Terhadap Siswa Kelas X SMK Negari 2 Karawang Tahun Ajaran 2017/2018. 823-828.

Thahar, H.,E. (2008). Menulis Kreatif. Padang: Universitas Negeri Padang Press.

Walef, S.,M. (2018). Pengaruh Pembelajaran Kooratif Tipe Jigsaw terhadap Keterampilan Membaca pemahaman pada Siswa Kelas VII SMPN 1 Kecamatan Guguak. 56-66

Yulia. (2017). Pengaruh Model Problem Bassed LearningBerbantuan media Audio Visual terhadap KeterampilanMenulis Teks Ulasan ?Riviu Film/ DramaSiswa Kelas XI SMA Semen Padang. 422-426 